\title{
Changing Directions in Russian-American Economic Relations, 1912-1917
}

In the nineteenth century Russia and the United States emerged as nations on the periphery of the West European economic and political vortex. Their relations with each other had been, for the most part, prompted by or integrated with some larger issue involving the powers of Western Europe. Economic relations were no exception. Both nations were traditionally exporters of raw materials to industrialized, urbanized nations, which in turn were prepared and eager to exchange manufactured goods for raw materials. Russian and American products were therefore competitive rather than reciprocal, and profitable mutual exchange of goods had not developed. ${ }^{1}$ Both nations were debtor nations and had relied on the surplus capital of the small and large investors of Western Europe to provide the beginnings of internal transportation and industrialization. ${ }^{2}$

Economic relations between Russia and the United States reached a low point in 1912 and 1913. Indifference to trade, as well as political and religious antagonisms, indicated only further deterioration. World War I soon brought cataclysmic changes that released Russia from the German economic ties under which she chafed and quickly transformed the United States from a debtor to a creditor nation and hastened her industrialization. These factors, combined with the exhaustion of West European nations, brought the United States and Russia critically face to face in direct relationships. To what extent would the old patterns change and what were the portents for the future?

Trade and commerce between Russia and the United States had been regularized by the Treaty of Navigation and Commerce of 1832 . James Buchanan, envoy extraordinary and minister plenipotentiary, negotiated for the

1. Cotton and agricultural machinery were the exceptions to this rule. The Russian cotton textile industry predated the development of cotton culture there; thus Russia purchased cotton from the United States. The U.S. farm implement industry produced machinery some of which was more appropriate for the extensive plains of Russia than European machinery. In addition, the International Harvester Company was unique among American industries in offering credit to Russian buyers. U.S. industry was not competitive with European industry in small farming equipment.

2. Here again there were exceptions in that there had been a small number of very wealthy Americans, such as J. P. Morgan, who were interested in speculative investment in Russia. 
United States, and Count Karl Nesselrode, foreign minister, acted for Russia. At the request of Nesselrode the greatest caution was observed during negotiations so that the British government would not learn that the treaty was in process. $^{3}$

The purpose of the treaty was to extend and consolidate commercial intercourse between the two nations. It provided that the inhabitants of both nations would have liberty to enter the ports, places, and rivers of the territories of each party wherever foreign commerce was permitted and be at liberty to sojourn and reside there to tend to their affairs with the same security and protection as natives of the country wherein they resided. Additional provisions dealt with the arrival and departure of vessels, arrangements for consuls and agents, disposal of personal goods, and withdrawal of proceeds, and granted the powers and privileges of most-favored nations. ${ }^{4}$ Negotiations proceeded smoothly, and the treaty was accepted enthusiastically by Tsar Nicholas I and ratified unanimously by the United States Senate.

Despite the treaty, economic ties between Russia and the United States grew very slowly and the volume of direct trade was never large. Indifference toward expansion of trade was marked and continuing on both sides. ${ }^{5}$ England continued as Russia's chief trading partner, often serving as the middleman in the exchange of goods and transfer of credits between the United States and Russia.

In the late nineteenth century Germany replaced England as Russia's chief trading partner, and as the twentieth century advanced the trend became more apparent. A trade treaty with Germany had been negotiated in 1904 which was favorable to German interests, but expansion of German trade in Russia was due more to promotional and credit methods than to the favorable trade treaty. ${ }^{6}$ Much of the American trade went through German channels because of Germany's dynamic trade methods and the lack of direct shipping lines between the United States and Russia. Germany was intensely unpopular in Russia, partly because it was believed that Germany had taken

3. From the dispatches of Buchanan transmitted with the treaty. Hunter Miller, ed., Trcaties and Other International Acts of the United States of America, vol. 3 (181935) (Washington, D. C., 1933), p. 737.

4. The treaty is stated in full in Miller (ibid., pp. 723-34). From the dispatches it appears that secrecy had been maintained during negotiation, for the British ambassador in St. Petersburg expressed surprise on the occasion of the signing of the treaty.

5. This fact has been well documented by V. V. Lebedev, Russko-amerikanskic ckonomicheskic otnosheniia, 1900-1917 (Moscow, 1964), and by Gilbert C. Kohlenberg, "Russian-American Economic Relations, 1906-1917," Ph.D. diss. (Urbana, 1951).

6. This is the view of I. M. Kulisher, Ocherk po istorii russkoi torgovli (St. Petersburg, 1923) and also of U.S. Department of Commerce, Bureau of Foreign and Domestic Commerce, Miscellaneous Series, no. 57, German Foreign Trade Organization (Washington, D.C., 1914). 
advantage of conditions after the Russo-Japanese War to force a burdensome treaty.

As far as capital investments were concerned, both Russia and the United States were debtor nations before 1914 , with foreign investment particularly important in the building of their railroads. Europe had investments of perhaps as much as $\$ 7$ billion in the United States-England being the largest investor. ${ }^{7}$ Russia had not been so richly endowed, but total foreign investments in industrial, banking, and commercial enterprises at the outbreak of the war were estimated at slightly more than $\$ 1$ billion, with France the largest investor. American investments in Russia were slight and had appeared rather late in comparison with those of highly developed West European countries. Anerican speculative motives aroused a certain amount of suspicion and resistance in Russia and caused American investors to seek areas easier to penetrate. On the eve of World War I, American capital in Russia totaled somewhat more than $\$ 60$ million, a mere 5 percent of all foreign capital investments in Russia. ${ }^{8}$

Indifference toward trade and limited financial involvement, coupled with American dislike for Russian policies with:regard to its Jewish population, culminated in the abrogation in 1912 of the eighty-year-old trade treaty between Russia and the United States. Hostility in the United States toward Russia's treatment of her Jewish population had been building up for at least three decades. Stringent regulations and their enforcement had resulted in the migration of about two hundred thousand Jews from the Russian Empire to the United States in the 1880 s alone. ${ }^{9}$ These new Americans were literate and vocal and remembered with bitterness the policies of the tsarist government toward their coreligionists. Once established in the United States, many of them were good prospects as trade representatives in Russia because of their knowledge of the language; others had property or family interests which impelled them to return to their homeland. Russian authorities were reluctant to admit such travelers, and interpreted the first article of the trade treaty to block their return.

Article 1 provided for reciprocal commerce and navigation between the

7. Russian Review, 1, no. 1 (February 1916): 35. The total of $\$ 7$ billion was documented from statistics of the U.S. Bureau of Foreign and Domestic Commerce.

8. An exact figure is impossible to compile. P. V. O1, Inostrannye kapitaly $v$ Rossii (Petrograd, 1922), p. 13, calculated the figure at 113,900,000 rubles of American investment. His figure has been generally accepted by American historians. Lebedev, Russkoamerikanskie ekonomicheskic otnosheniia, p. 18, believes the sum was $10,000,000$ rubles more than $\mathrm{O} 1$, or $123,900,000$ rubles. (Ol's figure of more than $\$ 1$ billion total foreign investment in Russia does not take into account large loans made directly to the Russian government before 1907.)

9. U.S. Congress, House, Committee on Foreign Affairs, Hearing on Termination of the Treaty of 1832 Between the United States and Russia (Washington, D. C., 1911), p. 147. 
two countries, and extended to citizens of each country the liberty to enter the territory of the other, subject to the rules and regulations of the country entered. American Jews wishing to return were disturbed by the refusal of Russian agents in the United States to visa their passports. Furthermore, the Russian government assumed that citizens who had left the country without the consent of the government were still citizens even though they had been granted citizenship by another nation, and as Russian citizens were subject to military conscription as well as other regulations pertaining to Jews.

The passport difficulties had passed the critical stage within a few years after the turn of the century. In 1911 the State Department reported that for the previous five years it had found only four cases of Jews who had been denied Russian visas on grounds of race or religion. ${ }^{10}$ But American antipathy for Russian policy continued at a high pitch because of reports from Russia of violence inspired by anti-Semitism.

American anger vented itself in a desire to abrogate the trade treaty. The first resolution to terminate the treaty was introduced in 1909. Memorials to the Congress requesting termination poured in from state legislatures. Sentiment in Congress, abetted by public pressure, built up to a climactic resolution in 1911 instructing the President of the United States to terminate the trade treaty. A huge mass meeting was held in New York City at which college presidents, bishops, bankers, congressmen, and politicians supported passage of the resolution. Presidential candidate Woodrow Wilson spoke at the meeting, saying that America was not a mere body of traders but a body of free men whose freedom was built on moral not material considerations. ${ }^{11}$ The resolution passed the House in December 1911 by an overwhelming majority. It stated that the people of the United States asserted as a fundamental principle that the rights of its citizens should not be impaired at home or abroad because of race or religion, that the government of Russia had violated the treaty by refusing to honor American Jewish passports, that the treaty ought to be terminated at the earliest possible date. The resolution charged the President with the duty of communicating such notice to the government of Russia.

Officials of both nations were distressed at the action of the Congress. The State Department felt that St. Petersburg was justified in insisting that there had been no violation of the treaty, ${ }^{12}$ and believed abrogation would endanger trade and other economic ties and weaken the U.S. position in dealing with Russia in the Near and Far East. Abrogation of a trade treaty on grounds of religious discrimination was hardly in line with the dollar diplomacy of

10. Thomas A. Bailey, America Faces Russia (Ithaca, 1950), p. 115.

11. Hearing on Termination, p. 15.

12. Bailey, America Faces Russia, p. 219; State Department Memo, Apr, 22, 1911, National Archives 711.612/55. 
President Taft, and he hastened to terminate the treaty as tactfully as possible before the Senate could pass a similar resolution further insulting Russia.

Secretary of State Knox had written previously to Ambassador Curtis Guild that to avoid the embarrassment likely to be produced by passage of the resolution pending in Congress it would be better to confer with the Russian government about mutually terminating the old treaty and negotiating a "more modern treaty."13 Guild conferred with the Russian foreign minister, S. D. Sazonov, who found it "incomprehensible that the United States should deliberately consider the sacrifice of a present and prospective market of hundreds of thousands of dollars, knowing that Russia in return sold so very little to the United States." Guild replied that America was completely misunderstood in Europe, that we were not a materialistic nation, but that the American point of view was that absolute freedom of speech and movement was the best cure for treason and conspiracy. Sazonov replied that in the Russian experience Jews were a "perpetual menace" to law and order and that Russia would never negotiate a treaty that did not explicitly give both nations the right to exclude general classes of persons deemed by each to be undesirable. He seriously stated that he was willing to consider an arrangement whereby all Russian Jews might be transferred to the United States. American Jews on legitimate business, he said, could visit Russia, but Russia would never permit free admission through which the United States or any other country might send back to Russia a Jewish nihilist to plot against the empire. Russia, he said, had faithfully observed the treaty, and the action of the United States was "unaccountable." No self-respecting nation, he concluded, would take action under pressure from abroad. ${ }^{14}$ President Taft therefore terminated the treaty unilaterally in line with the House of Representatives resolution.

Public reaction in Russia was similar to official reaction. A mass meeting was convened in St. Petersburg which was reported to be the first public gathering of protest ever sanctioned by the government. A bill, which failed to pass, was introduced into the Duma stipulating that the duty on American imports be increased to 100 percent and that all Jewish-Americans be excluded from Russia. The Russian press began to characterize Uncle Sam with the features of a Jew and played up the political power of the Jewish groups as providing money for political campaigns. Widespread boycotts were organized against American goods. ${ }^{15}$ Influential members of the Duma were convinced that Jewish bankers dictated American policy, ${ }^{16}$ although many probably agreed

13. U.S. Department of State, Papers Relating to the Foreign Relations of the United States, 1911 (Washington, D.C., 1918), p. 695. There was a provision that the treaty might be terminated on one year's notice.

14. Ibid., pp. 697-99.

15. Bailey, Amcrica Faces Russia, p. 120.

16. Krasmyi arkhiv, 64 (1934): 16-19. 
with Count Witte, who felt that Russia herself had driven the United States to this step.

The manner and cause of the treaty's abrogation and the fact that it had not been accepted gracefully in official circles or in the St. Petersburg press caused Ambassador Guild considerable embarrassment. When his efforts to negotiate a new treaty were unsuccessful, he was forced to abandon hope. He took a leave of absence, then resigned, and his post remained vacant for over a year. Presidents Taft and Wilson both made earnest endeavors to negotiate a new treaty without success.

The hostility of American public opinion showed no sign of abatement and was encouraged by newspaper articles and editorials. The New York Times reported that the secretary of the American Jewish Committee, who was "thoroughly acquainted with the history of Russia's treatment of Jews," was about to be appointed as the new ambassador and would place before the Russian government the unwillingness of the United States to negotiate unless Russia provided equal treatment for all citizens regardless of race or creed. ${ }^{17}$ The ritual murder charge trial of Mendel Beilis in Kiev was given great publicity. A petition signed by innumerable Americans, denying that Jews used the blood of Christians in ritual observances, was presented in Washington to the Russian embassy, which refused to accept it. ${ }^{18}$

Efforts to negotiate a new treaty were fruitless, and all attempts were blocked by political considerations rather than economic ones. The failure, in Lebedev's view, was due to weak interest in trade on both sides but particularly to lack of interest on the American side in building up long-tern expanding trade with Russia. ${ }^{19}$ Trade declined slightly in 1913, but no drastic change in the commercial relations of the two countries was produced by the treaty's termination.

In the broad view of American-Russian relations, termination of the trade treaty was only a part of the generally poor relations between the nations during the years before 1914. General disparity of social and political aims, rivalry in Persia and China, and slight trade and financial connections combined to create cool relations. "After 1895," says Pauline Tompkins, "the amity [between Russia and the United States] began a descending spiral which reached its nadir shortly before the First World War. . . Moreover, by 1914 the last vestiges of traditional American-Russian friendship had disappeared."20

17. New York Times, Sept. 29, 1913, p. 1.

18. Nezu York Times, Nov. 7, 1913, p. 3.

19. Lebedev, Russko-amerikanskie ekonomicheskie otnosheniia, p. 134.

20. Pauline Tompkins, American-Russian Relations in the Far East (New York, 1949), D. 29. 
After the termination of the trade treaty, Russia sought new channels to encourage direct trade with the United States. In 1913 the Russian-American Chamber of Commerce was chartered by the Russian government to bring about closer relations between the countries on common industrial grounds and interests. The idea had been conceived in Moscow by American and Russian government officials and businessmen, but organization was actually carried out by Russians. The Chamber of Commerce had a directorate of twenty-four leading businessmen of Moscow and St. Petersburg and many branches in Russia. It was commissioned to study and report on all matters that would tend to make free and direct commercial relations possible without German or English middlemen, and it also prepared a journal of trade opportunities for circulation to American businessmen.

In mid-1913 Dr. J. M. Imchanitzky was sent on an official visit by the Russian government to place a $\$ 3$ million order for refrigerator cars for use in Siberia and to learn about direct purchase of other products. Part of his task was to spread the word that the Russian government had an official interest in American products, particularly consumer goods. That the purpose of his visit was to help free Russia from German influence was apparent in his press interviews. "We make no hats in Russia," he said, "we import them from Germany. America makes very nice hats, and I am sure we would like the American hats better than those we are using." Imchanitzky reminded Americans that the two countries had never been at war and had often been friends and that their commercial men should find much in common. $\mathrm{He}$ lamented that Germany, France, and England controlled Russian markets, and said he felt this would not be the case if Americans and Russians knew each other better. He suggested that there were many possibilities for joining with Russian capital in exploitation of natural resources, and said it was no exaggeration to say that Russia was ready to be Americanized. ${ }^{21}$

C. J. Medzikhovsky was sent later in 1913 as a commercial attaché to the Russian embassy in Washington to promote direct trade. He was instructed to supply American businessmen with whatever information they needed about Russian markets and opportunities for trade and investment. He made a strong plea for more trade between the United States and Russia in the hope of eliminating German and English middlemen. According to Medzikhovsky, official records showed that imports from Russia to America in 1913 were only about $\$ 9$ million, when actually they were more than $\$ 30$ million. Official exports from the United States to Russia were listed as $\$ 25$ million, but were really about $\$ 80$ million. The divergence between official and actual trade figures resulted from the transactions of middlemen, particularly German

21. New York Times, July 13, 1913, sec. 2, p. 9. See also Kohlenberg, "RussianAmerican Economic Relations," p. 229. 
middlemen, who bought American goods and resold them in Russia.22 Medzikhovsky congratulated the American Association of Manufacturers for opening a branch in Russia, and Minister of Finance Kokovtsov supported them with a telegram of congratulation. ${ }^{23}$

The outbreak of war, destructive as it was to Russian trade routes and foreign access, presented Russia with an opportunity to stop the growing economic involvement with Germany. The moment hostilities began, embargo was declared on trade with Germany and the trade treaty was abrogatedas was to be expected. According to Boris E. Nolde, Russia used methods which were unique and new to the legal world in an effort to rid herself of the German trade alliance and financial grip. ${ }^{24}$ At the outbreak of hostilities the Russians had followed the traditional rule that the property of enemy nations was inviolate, but within a few weeks a new approach to economic warfare appeared. Sazonov declared that the struggle against German and Austrian nationals should be waged in the economic field "in order to set Russia free from economic domination by Germans." ${ }^{25}$ The first move came in September 1914 with the liquidation of German estates, the number of which had assumed alarming proportions in the western part of the country. In November 1914 a decree was enacted that prohibited money payments to enemy nationais. Further decrees issued in 1915 closed enemy concerns and liquidated jointstock companies controlled by enemy nationals, and in early 1916 compulsory sale of all securities held by enemy nationals was ordered. Economic interests and private rights of enemy nationals were attacked (according to the Minutes of the Council of Ministers) to release the economic system of the country from German influence.

With the outbreak of hostilities Russia looked even more hopefully to possibilities of direct ties with the United States. Charles S. Wilson, chargé d'affaires while there was no American ambassador in St. Petersburg, reported to Secretary of State Bryan that Sazonov had urged him to impress upon the United States government the great opportunity for America to take advantage of the elimination of Germany from their trade. ${ }^{26}$ Within a few weeks

22. For example, German exports to Russia in 1913 included $\$ 2,784,000$ in raw cotton, an item which very likely came from the United States (German Foreign Trade Organization, p. 140).

23. New York Times, Dec. 17, 1913, p. 8. Medzikhovsky's purposes were explicitly written up in U.S. Department of Commerce, Bureau of Foreign and Domestic Commerce, Special Consular Report, no. 61, John J. Snodgrass, Russia (Washington, D.C., 1913).

24. Boris E. Nolde, Russia in the Economic War (New Haven, 1928). Nolde was undersecretary of state for foreign affairs in the tsar's government and professor of international law at the University of Petrograd.

25. Ibid., p. 12.

26. Kohlenberg, "Russian-American Economic Relations," p. 191; State Department Archives, Wilson to Bryan, Aug. 24, 1914. 611.6131/75. 
George T. Marye was sent as American ambassador with the principal task of negotiating a new treaty. In early conversations Sazonov referred to the disadvantageous trade conditions between the United States and Russia, which had led to the great bulk of the trade being done by Germany, and said he hoped these conditions would not continue after the war. Marye was confident that a new treaty would soon be negotiated. There were no immediate negotiations, however, and Marye noted instead an unexplained trip by the Russian minister of finance, P. L. Bark, to England. ${ }^{27}$ The closer alignment with England that resulted from Bark's trip to London was later mentioned by Ambassador David R. Francis as accounting for the Russian change of mind about negotiating a commercial treaty with the United States at that time. Francis believed that the Russians came to resent British influence deeply, as they would have resented any country that occupied in Russia the position Germany had held before the war. ${ }^{28}$

Thus the war had not brought Russia the economic freedom and direct contacts with the United States that she desired. What had been interference by Germany was exchanged in 1914 for interference by England. All of the Allied nations were in great need of war materials and supplies. England was the major source at first, but soon orders became so heavy that they were placed in growing numbers in the United States. At a conference of the Allied Ministers of Finance in London in February 1915 it was decided to concentrate and centralize orders and payments in London. Orders for Russia began to be placed with American factories by the British. At a second economic conference in London the procedure for ordering was established, and a joint committee was formed which dealt with Allied orders in the United States. England was playing a guardian role between the United States and Russia, and Finance Minister Bark could not refuse these arrangements, for financial aid for Russia was imperative. ${ }^{29}$

Further strengthening of English control came in September 1915, when a $\$ 500$ million Allied loan was made by a syndicate of sixty American banks. England and France issued bonds in this country to cover the loan, and J. P. Morgan became the commercial agent for the expenditure of the money in the United States. In prewar times Morgan money had gone to Russia through England, and the practice continued now. England granted Russia a monthly credit of $£ 25$ million for purchases in America, and bound her to send gold to England and thence to America as collateral.

The Russians became more and more resentful of English control of their p. 40.

27. George T. Marye, Nearing the End in Imperial Russia (Philadelphia, 1929),

28. U.S. Department of State, Papers Relating to the Foreign Relations of the United States: The Lansing Papers, 2:311-12.

29. Nolde, Russia in the Economic War, p. 147. 
war orders and took action to by-pass English intervention and make direct contact with the United States. In the spring of 1915 an artillery commission was sent to the United States under the leadership of General A. V. Sapozhnikov, and made direct purchases without the approval of England. In the fall of 1915 a Russian Procurement Commission was created for direct contact in purchases of supplies. Russian agents concluded direct contracts with American firms, particularly for metals, medicines, machinery, instruments, and rubber. Russia paid for these orders through Olaf Aschberg, Swedish director of the Swedish-Russian-Asiatic Company, which was connected with the Russo-Asiatic Bank. ${ }^{30}$ Most purchases of military products, such as shells, rifles, machine guns, and cartridges, were still ordered by the English-dominated committee, which displayed antagonism toward the Russian Procurement Commission. By May 1916 the leadership of the Russian Procurement Commission thought the situation was critical. Sapozhnikov went to England to try to soften the English attitude, and he received favorable concessions. All new contracts were to be concluded through the commission. Two representatives of England were to sit on the commission but were not to have powers of decision. ${ }^{31}$

Meanwhile, relations between Russian and American financial interests were developing rapidly, particularly at the end of 1915 and throughout 1916. American indebtedness to Europe had been liquidated by Allied purchases in the United States, and her capacity for economic expansion abroad was greatly increased. Spurred by Russian encouragement, the absence of German trade, and the wartime opportunity to realize good profits, American interest extended not only to war products but to postwar prospects as well. The RussianAmerican Chamber of Commerce did much promotional work and was recognized by the Russian government as an official organ for that purpose. Medzikhovsky was very active during the war, acting particularly through the American Association of Manufacturers. The Russian Association of Commerce and Industry, organized in 1915, sent S. K. Kalamantiano as its representative to the United States to invite direct business relations with Russia. American capital was lauded as being particularly desired by Russia, because it had no political strings attached. Kalamantiano advised U.S. traders to make up for lost time and seek a larger share in the Russian market. ${ }^{32}$

American businessmen and financiers saw glowing prospects for postwar opportunities. New periodicals extolled the golden promises of Russia to be fulfilled by ingenious American businessmen. Russia, a journal of Russian-

30. Lebedev, Russko-amerikanskie ekonomicheskie otnosheniia, p. 160.

31. Ibid., p. 163.

32. See S. K. Kalamantiano, Possibilities of Success of Import and Export Trade Between Russia and the USA After Present Events (Odessa, 1914). 
American trade which began publication in 1916, told its readers that Russia had a buying population equal to that of Britain, France, Germany, and AustriaHungary combined, which had been stirred by a new spirit of efficiency and a desire for the conveniences of modern civilization. ${ }^{33}$ America could start a new market which would increase steadily for decades and be of the highest benefit to both manufacturers and labor.

The American public's widespread ignorance about Russia was mitigated by periodical articles informing readers of the simple facts of Russian geography, industry, agriculture, and way of life. Perhaps for the first time Russia was depicted as having the usual Western-style streets, shops, offices, buildings, and well-dressed people. Petrograd, after all, was not unlike Chicago, ${ }^{34}$ and the great potential of Russia was on the verge of development. Russia and America were presented as economic doubles-countries that had been consistently friendly with each other and could offer much to each other. ${ }^{35}$

In this new periodical literature the fact that Russia had been devastated by war and was enormously in debt seemed to be no obstacle. The war had done no serious harm to Russia's economy and resources, it was argued, and the burden of the war could be borne with comparative ease by the Russian people. The disordered currency would soon be brought back to the solid foundation of unquestioned convertibility. The financial problems of Russia after the war would be simple compared with those of other nations, the readers of Russia were assured, because of Russia's vast natural wealth.

The scholarly Russian Review compared the Russian stage of development to that of the United States after its Civil War. Peaceful economic penetration would cause as little harm as the United States had suffered from foreign capital infusion. Readers were told that foreign holdings of American stocks before the opening of the war were anywhere between $\$ 4$ billion and $\$ 7$ billion, ${ }^{36}$ which made Russia's prewar indebtedness of $\$ 1.1$ billion seem small. The 1913 per capita debt of France was $\$ 308$ and that of Great Britain $\$ 179$, compared to $\$ 52$ for Russia. ${ }^{37}$ Russia was teeming, it was said, with natural resources and a growing population that needed the "awakening touch"

33. Russia, 1, no. 1 (May 1916): flyleaf. Russian and American publications praised the new efficiency of peasant labor and the increased savings bank deposits which had resulted from the prohibition of vodka in 1914.

34. Moody's Magazinc, 19, no. 8 (August 1916): 473 (compares Petrograd to Chicago). Many articles appeared in Moody's enlightening its readers about Russia. If the authors judged their readers correctly, the public was indeed ignorant of the most simple facts about Russia.

35. Edwin Francis Gay, dean of Harvard Graduate School of Business Administration, writing in Russia, May 1916, p. 6, was one of many who presented this view.

36. Moody's Magazine, 19, no. 1 (January 1916): 3, reported that the figure ranged between $\$ 4$ and $\$ 6$ billion. The U.S. Department of Commerce figure, quoted earlier, was $\$ 7$ billion.

37. Moody's Magazine, 19, no. 4 (April 1916): 208. 
of the creative genius of American businessmen, whose breadth of vision and organizational abilities were unknown in Russia. Leo Pasvolsky wrote that the development of Russia's productive force was impossible without foreign capital, but warned that Russia was not Mexico or China, where capital could be given full freedom of exploitation. ${ }^{88}$ Fears of revolution were quelled by the idea that a revolution would be good for Russia, and that men such as Paul Miliukov, who knew that credit was the life blood of a nation, would lead it.

Ambitious schemes began to take form in 1915 for postwar trade and investment in Russia. In Lebedev's opinion the organization which conducted the most activity and had the greatest chance of success was the American International Corporation. ${ }^{39}$ Francis Vanderlip, president of the National City Bank, was the promoter, and the bank contributed half of the $\$ 50$ million capitalization. The corporation had twenty-four directors, including leaders of such companies as General Electric and Standard Oil. Medzikhovsky made a special report about the corporation to the Russian Ministry of Trade and Industry on November 25, 1915, stating that many American industries possessed reserves of accumulated (if not stolen, in Medzikhovsky's caustic view) capital, which they could comfortably transfer abroad either to South America, China, or Russia. Medzikhovsky believed they preferred Russia because of the problems of political instability elsewhere. ${ }^{40}$ Medzikhovsky took the view that such capital should be welcomed, because it did not involve political entanglements. This view was probably generally accepted in Russian official circles. One aspect of the American International Corporation which Medzikhovsky found displeasing was that it included companies which after the war would want to export goods rather than capital. Medzikhovsky supported the view that Russia should not import goods after the war and that it would be necessary to preserve or even raise trade tariffs.

Vanderlip worked through his representative in Petrograd, H. F. Meserve, directing him to negotiate for the opening of a branch bank there and to seek contacts with companies needing investment capital for presentation to the American International Corporation. A branch bank would be essential for direct investment of capital. Offers to invest capital went to all parts of Russia, but especially to Siberia. Members of the government and the Duma encouraged the operation. Duma member V. I. Timiriazev suggested

38. Russian Review, 3, no. 3 (July 1917): 17 .

39. Lebedev, Russko-amerikanskic ekonomicheskie otnosheniia, p. 220. Lebedev bases his discussion on notes and letters of G. L. Loris-Melikov, first secretary of the Russian embassy in Washington. According to Moody's Magazine, 19, no. 1 (January 1916): 39, the American International Corporation was formed November 23, 1915, with a capital of $\$ 50$ million to develop American foreign trade.

40. R. Sh. Ganelin, "Politika tsarizma i amerikanskii kapital vo vremia Pervoi Mirovoi Voiny (konets 1915-nachalo 1916)," pp. 321-63 in Akademiia nauk SSSR, Vnutrenniaia politika tsarizma (seredina XVI-nachalo $X X$ v.) (Leningrad, 1967). 
infusion of American capital into the automobile, machine tool, and cotton textile industries. Duma member A. I. Shingarev supported investments in metallurgy, and V. I. Kovalevsky in the chemical industry. The minister of finance helped in spreading information to private banks, and A. I. Guchkov gathered in his home representatives of banks and large industrial organizations to discuss possibilities.

Real developments were extremely slow, however, and were hampered by the arguments of those in Russia who opposed such capital infusion. Government officials and large industrialists generally welcomed the opportunity to be free of European capital, but were skeptical and wary about the advisability of any foreign capital intrusion in a variety of industries across the country. They felt that this would only mean exchanging the controlling influence of Germany for that of another nation. They preferred large credits that could be rationally directed and regulated by the Russians themselves. Since Russia must advance toward industrial self-sufficiency, and the only known way to do it quickly was to borrow foreign capital, the Russians felt that it was almost inevitable for them to rely on American capital. ${ }^{41}$

Railroad building was the one area in which there was mutual agreement between Russian businessmen and American investors. Many projects were considered and a few were actually begun. In January 1915, conversations initiated through the American International Corporation resulted in a contract late in the same year with a Chicago firm to construct 1470 versts of railroad for the Moscow-Kazan joint-stock railroad company. The prospect of a railroad from Moscow to the Donets Basin seemed especially attractive, and was talked of as the "crown of all railroads." Eventually it was to extend to Lugansk and Taganrog. Engineers connected with the American International Corporation investigated economic conditions in the Donets Basin in May 1916, and in January 1917 negotiations began with the Russian government for the actual construction. Coal and iron ore for the metallurgical and machine-building industries were to be the main items of transport.

There was also much interest in expanding the port of Vladivostok and improving the Trans-Siberian Railway. Late in the spring of 1917 the American International Corporation and the Provisional Government took up this project enthusiastically in what was later to become the Holbrook Project. American interest in Russian railroads predated the war, going back to the first decade of the twentieth century when Morgan interests had wanted to buy the Trans-Siberian. Now the interest revived and intensified and was augmented by the worthy desire to expedite the flow of supplies from

41. Lebedev, Russko-amerikanskie ekonomicheskie otnosheniia, pp. 222-27. Also Ganelin, "Politika tsarizma," p. 360. 
the port of Vladivostok to the military front. Enormous quantities of American supplies were piled on the open shores of the port awaiting transportation that would not be available for months-possibly years. Before U.S. entry into the war, American railroad interests had sent the Stevens Commission to investigate and expedite the development of the Russian railroads.

Several loans had been made to Russia by American bankers before the United States entered the war. Russia was desperately in need of money, and wanted it to be free of English control, but found American terms distasteful. The first loan was made in October 1914 by National City Bank, largely as a bank transaction to cover orders from Russia in process. President Wilson had declared that America would not lend to belligerent nations, but upon inquiry from National City Bank replied that how private merchants financed their own affairs was their business and did not need government consent. ${ }^{42}$ National City Bank consequently lent $\$ 5$ million in exchange for Russian government short-term treasury notes. Other short-term credits were granted to Russia on similar terms by National City Bank in $1915 .{ }^{43}$

In 1915 the Russian government began to make more serious and aggressive efforts to borrow directly from the American money market in order to by-pass England. A number of feelers went out, some through Russian members of the embassy connected with financial circles. Another went through Olaf Aschberg, who was given the task by the Russian government of obtaining direct credit for them in America. Aschberg was one of the founders of the Swedish-Russian-Asiatic Company, which had branches in Petrograd, Stockholm, and New York. He received a favorable response at the Guarantee Trust Company, which (in syndicate with five other banks) offered to lend $\$ 60$ million in return for guaranteed Russian railroad obligations. ${ }^{44}$

Conversations about the loan began in January 1916 between representatives of the banks and Minister of Finance Bark, but consummation was delayed for weeks by disagreement over collateral, size of loans, interest rates, and fear on the Russian side that the capital could not be repaid and the Americans would acquire the railroads. Equally crucial to the decision was the fear that England would be jealous of any divergence of credit, since she had guaranteed payment of Russia's military orders in the United States. The Committee of Finance therefore rejected the proposed loan in mid-

42. Lansing Papers, 1:136-37.

43. Lebedev, Russko-amerikanskie ekonomicheskie otnosheniia, pp. 251-52.

44. Ganelin, "Politika tsarizma," p. 332. The negotiations are explained in great detail by Ganelin (pp. 350-57), based on correspondence in the TsGIA (fonds 624 and 630) between the bank in New York, its representatives in St. Petersburg, and the Ministry of Finance. Upon request of the writer of this article, the Guarantee Trust Company (which incorporated Morgan interests) has advised that it does not find in its archives any files of the correspondence that Ganelin quotes. 
March, phrasing the refusal so that it would not discourage the Americans; but stating that the Russian government would wait a while. Privately Bark expressed the opinion that the conditions were too severe and that it was necessary to be firm with the Americans about conditions for loans. Almost immediately after the refusal Bark invited Meserve to come for further conversations, and in April 1916 the National City Bank lent the Russian government $\$ 11$ million for a term of one year at 5 percent interest. The loan was later renewed to May 1918. As security the Russian government pledged their internal bonds.

Finally, in June 1916 a syndicate of American banks, headed by National City Bank, made a loan of $\$ 50$ million to the Russian government after long negotiation. In May American Ambassador Francis had written to Secretary of State Lansing that negotiations had been pending for three to six months and that Sazonov had told him Russia would not accept the proffered loan, because "the American bankers demanded specific security in addition to the faith of Russia." 45 The loan finally took form in a highly speculative balancing of credits, with $\$ 50$ million credit being placed in the New York bank against which Russia could draw in payment for munitions and supplies in the United States, and 150 million rubles being placed in Russian banks which could be turned into five-year government bonds at any time within three years. This arrangement was highly speculative for American investors because the credit was established with the exchange value of the ruble at 33 cents, though the standard rate was 51.5 cents. A. W. Ferrin, writing for Moody's Magazine, judged this a remarkably good investment, for if the exchange value should rise to the standard rate, the 150 million rubles would be worth $\$ 76.5$ million, or a "clean" profit of $\$ 26.5$ million, half of which was to be shared with the Russian government. ${ }^{46}$ Critics suggested that unfair advantage was being taken of Russia.

The final loan to the government of Nicholas II was made in November 1916, in the form of an agreement of the syndicate headed by National City Bank to sell on the American market Russian state treasury obligations up to the amount of $\$ 25$ million. For those American investors willing to take a long chance, bonds of the Russian Internal Loan, payable in rubles in Petrograd in 1920, could be bought over the counter in New York. Several hundred thousand dollars were invested in this way.

Negotiations to open a branch of National City Bank in Petrograd continued to be delayed by disagreements over regulations. In the summer

45. Lansing Papers, 1:148-49. Sazonov complained to Francis on another occasion that American bankers were demanding specific collateral and that Russia would make no loan that required security other than faith and credit.

46. Moody's Magazine, 19, no. 7 (July 1916): 373-74. 
of 1916 Samuel McRoberts and Charles V. Rich, vice-presidents of the bank, went to Petrograd to assist Meserve and expedite negotiations. The branch was finally opened in January 1917, with a capital of $\$ 50$ million. ${ }^{47}$

In April 1916 Wilson had appointed David R. Francis as ambassador to Russia with the mission of negotiating a new trade treaty. Francis was a politician and a businessman, not particularly sophisticated in the ways of international diplomacy. He was enormously impressed by Russia's wealth, and believed American merchants should get a "firm foothold" in Russia while the opportunity presented itself. American capital should be encouraged in order to offset the well-designed plans of England, and perhaps France, to capture the trade of Russia after the war. ${ }^{48}$

Francis called on Sazonov immediately after his arrival to discuss a commercial treaty. Sazonov advised him that Russia was not interested at the moment and would not be until after the meeting of the Allied Economic Conference in Paris in June 1916. After the conference postponement continued and Francis was unsuccessful in negotiating a trade treaty, much to his disappointment, he judged that the treaty was being blocked by English influence. The Economic Conference itself, he believed, was inspired by England in an effort to occupy in Russia the position that Germany had held before the war.

Francis was correct in judging England's purpose at the Allied Economic Conference but possibly did not anticipate Russia's response. The conference was called to discuss Allied unity in the prosecution of the war and to make preparations for the postwar period. English Prime Minister Asquith told the House of Commons that the purpose of the conference was to adopt measures to secure for the Allies and neutral countries full economic independence and respect for sound commercial practices. "The war," he said, "has opened our eyes to the German system of economic penetration." $\mathrm{He}$ added that it was impossible to believe that Germany would not be motivated by the same spirit and policy when the war was over. The English hoped to prohibit trade with Germany for a stated number of years through a tariff union. ${ }^{48}$

In the Russian view it appeared that this was an effort to extend the wartime arrangement of English economic influence in Russia. N. N. Pokrovsky, foreign minister, led the Russian delegation, which was intensely interested in the postwar economic policy of the Allies, and the idea of ridding Russia of all foreign influence was evident among the delegates.

47. Lebedev, Russko-amerikanskie ekonomicheskie otnosheniia, pp. 268-69.

48. David R. Francis, Russia from the American Embassy (New York, 1921), p. 25. 1916): 333 . 
Much as they had earlier resented the German trade treaty, they now opposed the British and French idea of establishing a double tariff system after the war-one favorable to the Allies and a higher one for Germany. Pokrovsky's instructions stated that to avoid the enslavement of Russian industry there must be autonomous tariffs, fixed not by trade agreements but by legislative chambers in accordance with the needs of the country. ${ }^{50}$ Nevertheless, the English and French view prevailed in the resolutions adopted by the conference. The ultimate decision concerning acceptance of the resolutions fell to the Provisional Government, which refused to ratify them, considering in their refusal not only that they did not want to be bound to England and France but also that the United States was antagonistic to the principles of the conference.

The collapse of the autocracy and the advent of the Provisional Government, coupled with American entry into the war and the weakening financial condition of England, strengthened relations between the United States and Russia. The United States extended immediate recognition. The autocracy, President Wilson declared, had been shaken off by the great, generous Russian people who had thus become fit partners for a league of honor. ${ }^{51}$ The Provisional Government quickly abolished restrictions on Jewish citizens, removing that impediment to closer relations with the United States. Arrangements were immediately started in Petrograd to send to the United States a special economic-financial mission to broaden political, economic, and financial connections. ${ }^{52}$ Ambassador Francis, naively enthusiastic about the strength of the new government, immediately recommended extending a credit of $\$ 500$ million, and Finance Minister Tereshchenko also hoped the United States would grant credit of $\$ 500$ million, independent from England. American entry into the war in April removed legal and diplomatic barriers to government aid to Russia. From May to October 1917 the United States government opened credit to Russia totaling $\$ 325$ million, of which Russia had drawn nearly $\$ 200$ million before the October Revolution, ${ }^{63}$ for purchases of munitions and supplies in the United States.

The government loans were made expressly for the pursuit of the war, but there was also increasing interest in postwar financial connections. The Russian-American Chamber of Commerce stepped up its activities for the

50. Nolde, Russia in the Economic War, pp. 159-63.

51. Papers Relating to the Foreign Relations of the United States, 1917, p. 200.

52. Akademiia nauk SSSR, Ekonomicheskoe polozhenie Rossii nakanune Velikoi Oktiabr'skoi Sotsialisticheskoi Revolutsii: Dokumenty i materialy, part 2 (Moscow, 1957), p. 453, letter of Foreign Affairs Minister Miliukov to the Ministry of Trade and Commerce, Mar. 16, 1917, and numerous other documents.

53. Alexander M. Michelson, P. N. Apostol, and M. W. Bernatzky, Russian Public Finance During the War (New Haven, 1928), p. 313. Another $\$ 125$ million was granted Nov. 1, 1917, but was canceled in December 1917. 
investment of American capital. ${ }^{54}$ Missions were exchanged to convey the new feeling of friendship, to expedite the conduct of the war, and to explore the possibility of closer postwar connections. Elihu Root, a former secretary of war and secretary of state, as well as retired manufacturer, was handpicked by President Wilson to head the American mission. Other members were carefully chosen to represent business, labor, banking, and humanitarian interests. The Russian mission to America, headed by Boris A. Bakhmetev, assistant minister of trade and industry, was also carefully selected. Bakhmetev stated that the Provisional Government expected to turn increasingly to the United States for aid along many different lines, especially concerning financing, railroads, agriculture, munitions, and supplies.

The Provisional Government did not display the caution that the government of Nicholas II had shown toward involvement with American capital. There were complaints, however, about American motives. There was resentment in Petrograd, for example, regarding the attitude of the Stevens Commission and its efforts to "run" the Trans-Siberian Railway. ${ }^{55}$ There was apparently suspicion that the activities of the Red Cross were not completely humanitarian, that it was interested in getting control of coal and petroleum interests in European Russia, and that it was supported by extensive capital and banking interests. ${ }^{56}$ But the desperate and precarious position of the Provisional Government forced it to accept American capital in order to retain power and continue participation in the war. The hope that American capital could be accepted without political entanglements was quickly blasted by American insistence on participation in the war to a victorious conclusion.

Economic relations between Russia and the United States had seemingly reversed their course between 1912 and 1917. The indifference toward trade so evident in 1912, particularly on the American side, had disappeared. American investment capabilities had expanded, Russian needs were enormous, and on both sides there was a willingness to deal. It is probable that the immediate future, without the October Revolution, would have seen some continued extension of direct economic ties.

Many obstacles, however, stood in the way of the workability of the new course, despite the mutual enthusiasm of 1916 and early 1917. United States public opinion and many of the political and economic leaders were unduly optimistic about the political atmosphere in Russia, the Russian market, and accessibility of natural resources. Russia, for her part,

54. Ekonomicheskoe polozhenie Rossii, p. 454 and elsewhere. $1: 111$.

55. Papers Relating to the Foreign Relations of the United States, 1918, Russia,

56. Lebedev, Russko-amerikanskie ekonomicheskie otnoshemiia, pp. 348-49. 
wanted and needed the products of American industry, but her own export possibilities had not changed for the better. With the return of peace the industrialized nations of Western Europe might well be more natural trading partners for Russia, and certainly a revitalized postwar England, France, and Germany would not leave the way completely clear for United States trade and investment. The breaking of former economic patterns, along with the emergencies of wartime, had led to direct relations between Russia and the United States. The absence of trade with Germany and the easing of financial ties with England and France during the war, combined with the years of American neutrality, had led to wishful thinking in Russia about freeing herself from dependence on European nations and aligning with a distant, politically disinterested power.

In reality, Russia had not escaped her position of economic dependence. On the contrary, the debt, defeat, and destruction of war had weakened her economic structure and greatly increased her need for huge amounts of capital and goods. Even the weak government of the final years of tsardom and the hard-pressed Provisional Government had observed with disquiet the speculative interests of American capital and the difficulties in regulating and controlling such capital to serve Russian needs rather than American profits. American credits extended during the war years had quickly proved to have demanding political involvements, no less compelling than those of European capital. Prolonged American capital participation might well extenuate the semicolonial economic posture of Russia, with the United States replacing European nations as the dominating power. On the eve of the October Revolution the problem of Russia's economic dependence continued, leaving a great unresolved problem for successive regimes. 